\title{
Inclusive education program in the division of Antipolo City: Basis for implementation model
}

Comia, Bernie $\square$

Emilio Aguinaldo College, Philippines (bernie.comia@aps.edu)

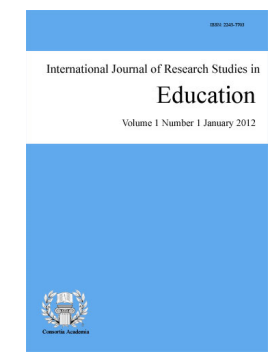

ISSN: 2243-7703

Accepted: 30 May 2021

OPEN ACCESS

\section{Abstract}

The study aimed to determine the implementation of an inclusive education program in Antipolo City as assessed by the five groups of respondents. Namely, School Administrators, Non-teaching personnel, SPED teachers, Regular teachers, and Parents school year 2017-2018. The study used a descriptive method of research method utilizing survey design with the aid of a questionnaire checklist as an instrument to gather the needed data. The target respondents were the School Administrators, non-teaching personnel, SPED teachers, regular teachers, and parents chosen through stratified sampling. They were asked to accomplish the survey instrument with three phases: Initial Phase, Transition Phase, and Inclusion Phase. It was found out that the School Administrators, SPED Teachers, Regular Teachers, and Parents Always performed their roles in the different phases of the Inclusive Education Program. In contrast, the Non-Teaching Personnel Often performed their roles in implementing the Inclusive Education Program in the Division of Antipolo City. Further, it was found out that the level of performance of the learners improved after attending the inclusion program, and they are still manageable. Therefore, they can expect achievement and progress in both academic performance and behavior. The findings reveal that the growth of inclusive education programs in Antipolo City has been relatively good support by the different implementers providing the other components. In general, the Inclusive Education Program in Antipolo City was a very important factor that greatly contributed to the learning of children with disabilities. Based on the findings of the study, the paper concluded that Child Find is the heart Education Program. Furthermore, the School Administrators, SPED Regular Teachers, and Parent performed their roles effectively in implementing the Inclusive Education Program in Antipolo City. Likewise, the Inclusive Education Programs require strong Administrative Support and Family Involvement to successfully implement an inclusive Education program to attain quality, relevant, and responsive special education.

Keywords: inclusive education; special education; initial phase; transition phase; inclusion phase 


\section{Inclusive education program in the division of Antipolo City: Basis for implementation model}

\section{Introduction}

Access to quality education is a human right. It is a birthright that all people possess under being human. Unfortunately, not all people in society enjoy this right which is derived from their inherent dignity. This fact is not only limited to the able ones but every individual. Therefore, even the most disabled should have an educational and living environment as close to normal as possible. Under the principle of normalization, both the means and the ends of education for students with disabilities should be as much like those non-disabled students to become culturally normative as possible and establish and/or maintain personal behavior and characteristics.

During the past years, a considerable world gradually accepts special education to be part of the educational system; hence, Special Education provides a wide range of support, programs, and services. In addition, it continues developing its features to cater to people with exceptionalities/disabilities. This only implies that even children with special needs have the right to be educated or to be in class which started further in children and youth welfare of the Civil Code of the Philippines, Chapter 1, and article 74 and to wit:

"Special classes where need warrant, there shall be at least special classes in every province and if possible special schools for physically handicapped, the mentally challenged and specially gifted. The private gestalt shall be given all the necessary inducement and encouragement to such classes for schools."

Through this article, the State shall take an initial move to give quality education for all. It describes that children shall meet the education based on their needs and make the learning process accessible. In line with this, special education is included to have this privilege in the educational process with proper implementation of the curriculum in all levels called inclusion.

Enclosure No. 1 to DepEd Order No. 72, s. 2009 stated that special education in the Philippines has only served $2 \%$ of the targeted 2.2 million children with disabilities who live without access to basic human rights: the Right to Education. Most of these children live in rural and far-flung areas, whose parents need awareness of educational opportunities that these children could avail themselves. It is stated in DepED Order no. 72 s. 2009 that inclusive education is a strategy for increasing the participation rate of children. The Department of $\mathrm{V}$ Education has organized the urgency to address this problem and, therefore, guarantee the right for these children to receive appropriate education within the regular classroom setting. Inclusive education embraces the philosophy of accepting all children regardless of race, size, shape, color, ability, or disability with support from school staff, students, parents, and the community.

As stipulated in DepEd Order 117, s. 1997, Sped programs in all levels must be institutionalized to achieve the totality of inclusive education in the Philippines. This is according to the education for all advocacy in selected public schools offering sped programs that cater to and accommodate children with special needs. Department of Education (2017) ensures inclusive education for learners with special needs. Up to date, DepEd has recognized a total of 648 SPED centers and regular schools offering the program -71 of which are catering to 1 Elementary students and 177 are catering to High School Students. Under the Inclusive Education program of the Department of Education are the Instructional programs: self-contained, itinerant teaching, resource room, pull-out, integration/mainstreaming, and the inclusion that refers to the enrollment of a child with special needs in a regular class with support services.

Central to inclusion is the human right to education as declared in the Universal Declaration of Human Rights. Through education, each human being develops his/her full personality, respects rights, understands, tolerates, and 
establishes friendships with persons who significantly differ from him/her in terms of race, religion, ability, and other diversity factors (UNESCO, 2005). Inclusive education sounds pleasing to the ears, but the essence of its facets would not be profitable to the children with special needs if it is not implemented and known by the qualified and competent special and regular teachers. Even though there is a deep promotion and force order for inclusive education, there is a lack of full implementation in the schools with sped programs. Therefore, all the persons involved are not fully aware of the whole process of inclusive education. As a result, the program lacks success, and all the things must fall into place for evaluation and improvement.

Regular and Special Education teachers play an important role in the lives of children with special needs. They are the ones who are responsible for the educational needs of these children. As a result, these children will require various services, modifications, and accommodations in their educational experiences. All the components for a comprehensive, inclusive program for children _ with special needs are given, including the phases and roles of DepEd officials in the implementation of inclusive education. The Department of Education is giving an excellent Special Education in the Philippines. It is on the right path because it is now strengthening the meaningful linkages between special and general education classrooms. This was aligned to the DepEd Order 53, s 2008 about maximization of Trained teachers and administrators in special education. Enclosure No. 2 to DepEd Order No. 72, s. 2009 stated the roles of DepEd officials in the implementation of inclusive education, namely, administrators, regular teachers, SPED teachers, non-teaching personnel, and parents.

All the five officials stated above are working closely to the inclusion program because they could use any of all the policies and practices discussed to implement into preschool inclusion programs. The implementation of inclusive education has three phases, namely, initial, transition, and inclusion phases. The initial phase pertains to the time when the school prepares for the implementation of inclusive education. The transition phase includes the period covering initial meetings done by the school personnel and other activities. In contrast, the inclusion phase is when children with special needs are admitted to the regular classes. This study looked at the implementation of inclusive education in schools. Thus, this study was conducted to assess how implementing an inclusive education program performs its roles and determine the extent of implementing an inclusive education program in the Division of Antipolo City.

\subsection{Significance of the study}

This study focused on the program implementation of inclusive education in different public schools in Antipolo City. Inclusive Education Program in the Division of Antipolo City caters to various children with special needs in education such as autism, intellectual disability, down syndrome, hearing impairment, physically handicapped, attention deficit hyperactivity disorder or ADHD, and cerebral palsy. These children with special needs are given the same privileges, just like children in the regular classroom. The extent of implementing inclusive education programs relative to its initial phase, the transition phase, and inclusion phase has to be given great consideration to effectively implement inclusive education in public elementary schools. In addition, there will be a certain gap between the special and general education system because of their differences in accommodation, modification, and identification of disabilities. There is a mismatch in the specialization of teachers handling inclusion programs in the regular setup. Many regular teachers don't have experiences, seminars, or units in Special Education or psychology to handle these learners.

General concerns are addressed, including children with special needs in a regular classroom. First, the teachers should have open communication with the sped teachers, parents, and to his/her principal. Every performance must take note to monitor the progress of the child. Second is the continuous communication or IEP (Individualized Education Plan) meeting in which the implementers must be visible and functional every time they are needed. Implementing inclusive education is impossible without the help of the stakeholders who are giving their support, especially in monetary terms. Ricci (2010) posited that there is a wide difference between regular and special education. For example, according to admission, test, readiness, and coping skills, SPED classes need a standardized recommendation on their personal needs compared to regular classes with standards 
are needed in regular classes while in SPED recommendations and their personal need is the standard. Moreover, in a classroom setup, the ratio of the regular class is one too many, while in SPED, the ratio is less for one-on-one teaching, small groups, and learning areas. Finally, in terms of evaluation, regular classes have a grading system with numerical or use letters. In SPED, narrative reports and assessments in all areas of learning are required. Specifically, regular teachers struggle greatly with making and implementing meaningful and purposeful accommodations and modifications for students with special needs (Cagney, 2009).

The researcher wanted to sustain and make a clear implementation of inclusive education in different public schools with the Sped program for the benefit of the regular teachers. They are handling special education programs and future teachers. They are involved in the process of special education. This required them to undergo training to improve their ability to educate and meet children with special needs inside their classrooms. General education teachers received many content specific courses during their college training, while special education teachers concentrate on disability specific knowledge. The focus subject on specific courses allows a greater depth and breadth in the content of specific knowledge in the general education classroom, where the general educators are experts.

DepEd Order 53, s. 2008, Maximization of Trained teachers and administrators in Special Education, gave importance to the present condition of our educational system. It reiterated that we should focus on learning and knowing all about Special Education and that the learning should not only focus on the sped teachers but also the school administrators, regular teachers, non-teaching personnel, and the support of the parents. This study is advantageous not only to the teachers and students with needs but also to the administrators to determine the proper and suited seminars and conferences given to their subordinates, which are the teachers. Conversely, to be fully engaged in the progress of the general classroom, students with disabilities need more than to be physically present in the classroom. They need group individualized instruction, supplementary aids and services, accommodations, and modifications to which they are entitled.

Inclusion components underpin the rationale for this research: the child find, assessment, program options, curriculum modification, and parental involvement and its related factors to be considered for a successful inclusive education. Before, children with special needs were often placed in a self-contained class or special education class. They have never been placed in a regular class. Well, there are many instances where inclusion has benefited both regular students and special education students. European Agency (2010) stated that to achieve a successful inclusive education, teachers must have certain knowledge and understanding of different learners' needs, teaching techniques, and curriculum strategies. These are the key factors for successful inclusion. Thus, this study was conducted to determine the performance and competence of the teachers' respondents in inclusion. Based on the factual evidence that special education programs in the locale of the study, specifically the general teachers, must be prepared to handle children with special needs in a regular class or setting.

\section{Methodology}

This study utilized the descriptive - evaluative, and documentary analysis method of research. As widely accepted, the descriptive research method is a fact-finding study that involves adequate and accurate interpretation of findings. Descriptive research describes a certain present condition. Relatively, the method is appropriate to this study since it aims to describe the implementation of the inclusive education program. The documentary analysis is appropriate in this study because it enables the researcher to formulate generalizations and find evidence that supports the study's evaluation. The researcher used this kind of research considering the desire to acquire first hand data from the respondents to formulate rational and sound conclusions and recommendations for the study. Furthermore, according to Clause (2014), this research method is used when the researcher wants to describe specific behavior as it occurs in the environment. The descriptive method of research was used to gather information about the present existing condition. Since this study focuses on implementing the inclusive education program, the descriptive evaluation and documentary analysis methods are the most appropriate methods to use. 
Descriptive research describes data and characteristics about the population being studied. It answers the question of who, what, where, when, and how. Descriptive research is used to obtain information concerning the current status of the phenomena to describe "what exists" concerning variables or conditions in a situation. The method involves a range from the survey, which describes the status quo. The researcher used the Evaluative Method of research to find out if the implementation of Inclusive Education Program through the process of evaluation using a questionnaire checklist will be acceptable. The article of Winsett (2014), entitled "Evaluative Research," defines evaluation is a systematic assessment of the operation and/or the program's outcomes or policy. It helped the researcher categorize and summarize the data to obtain the needed answers to the research questions about implementing an inclusive education program in Antipolo City.

\section{Findings and Discussion}

\section{Table 1}

Role performance of the implementers as assessed by the five groups respondents in the initial phase

\begin{tabular}{|c|c|c|c|c|c|c|c|c|c|c|c|c|}
\hline \multirow{2}{*}{$\begin{array}{l}\text { Five - Group } \\
\text { Respondents }\end{array}$} & \multicolumn{2}{|c|}{ Administrator } & \multicolumn{2}{|c|}{$\begin{array}{l}\text { Non- teaching } \\
\text { personnel }\end{array}$} & \multicolumn{2}{|c|}{$\begin{array}{c}\text { SPED } \\
\text { Teachers }\end{array}$} & \multicolumn{2}{|c|}{$\begin{array}{l}\text { Regular } \\
\text { Teachers }\end{array}$} & \multicolumn{2}{|c|}{ Parents } & \multicolumn{2}{|c|}{ Overall } \\
\hline & $\begin{array}{c}\text { Overall } \\
\text { Mean }\end{array}$ & VI & $\begin{array}{l}\text { Overall } \\
\text { Mean }\end{array}$ & VI & $\begin{array}{c}\text { Overall } \\
\text { Mean }\end{array}$ & VI & $\begin{array}{c}\text { Overall } \\
\text { Mean }\end{array}$ & VI & $\begin{array}{c}\text { Overall } \\
\text { Mean }\end{array}$ & VI & $\begin{array}{c}\text { Overall } \\
\text { Mean }\end{array}$ & VI \\
\hline 1. Administrator & 4.68 & $\mathrm{~A}$ & 3.64 & $\mathrm{O}$ & 4.25 & $\mathrm{~A}$ & 4.38 & A & 4.14 & $\mathrm{O}$ & 4.24 & $\mathrm{~A}$ \\
\hline $\begin{array}{l}\text { 2. Non-teaching } \\
\text { personnel }\end{array}$ & 3.7 & $\mathrm{O}$ & 3.8 & $\mathrm{O}$ & 3.5 & $\mathrm{O}$ & 4.24 & A & 4.24 & A & 4.06 & $\mathrm{O}$ \\
\hline $\begin{array}{l}\text { 3. SPED } \\
\text { Teachers }\end{array}$ & 4.67 & $\mathrm{~A}$ & 4.6 & A & 4.67 & A & 4.54 & A & 4.33 & A & 4.49 & A \\
\hline $\begin{array}{l}\text { 4. Regular } \\
\text { Teachers }\end{array}$ & 4.33 & A & 4.13 & $\mathrm{O}$ & 4.22 & A & 4.61 & A & 4.56 & $\mathrm{~A}$ & 4.48 & $\mathrm{~A}$ \\
\hline 5. Parents & 4.4 & A & 4.3 & A & 4.65 & $\mathrm{~A}$ & 4.65 & A & 4.45 & A & 4.52 & $\mathrm{~A}$ \\
\hline Grand Total & 4.36 & $\mathrm{~A}$ & 4.09 & $\mathrm{~A}$ & 4.26 & $\mathrm{~A}$ & 4.48 & $\mathrm{~A}$ & 4.34 & $\mathrm{~A}$ & 4.36 & $\mathrm{~A}$ \\
\hline
\end{tabular}

Legend. A - Always, O- Often, and So- Sometimes.

The result describes that only the non-teaching personnel evaluated as often doing their roles in the initial phase among all the implements. This result emphasized that non-teaching personnel are the least expected implementer in the inclusive education program. Yet, their presence must be felt, most especially by the parents. However, the findings explain that the parents, Sped teachers and regular teachers are the three (3) most important factors that greatly contribute to the implementation of inclusive education in the Initial Phase. This affirms to the findings of Biddle (2008) that regular and special education teachers need the time to work together to develop appropriate accommodations for students with disabilities. Together, they can develop various learning strategies and accommodations that will help foster success for all students in the general education classrooms.

\section{Table 2}

Role performance of the implementers as assessed by the five groups respondents in the transition phase

\begin{tabular}{|c|c|c|c|c|c|c|c|c|c|c|c|c|}
\hline \multirow{2}{*}{$\begin{array}{l}\text { Five - Group } \\
\text { Respondents }\end{array}$} & \multicolumn{2}{|c|}{ Administrator } & \multicolumn{2}{|c|}{$\begin{array}{l}\text { Non- teaching } \\
\text { personnel }\end{array}$} & \multicolumn{2}{|c|}{$\begin{array}{c}\text { SPED } \\
\text { Teachers }\end{array}$} & \multicolumn{2}{|c|}{$\begin{array}{l}\text { Regular } \\
\text { Teachers }\end{array}$} & \multicolumn{2}{|c|}{ Parents } & \multicolumn{2}{|c|}{ Overall } \\
\hline & $\begin{array}{c}\text { Overall } \\
\text { Mean }\end{array}$ & VI & $\begin{array}{c}\text { Overall } \\
\text { Mean }\end{array}$ & VI & $\begin{array}{c}\text { Overall } \\
\text { Mean }\end{array}$ & VI & $\begin{array}{l}\text { Overall } \\
\text { Mean }\end{array}$ & VI & $\begin{array}{c}\text { Overall } \\
\text { Mean }\end{array}$ & VI & $\begin{array}{c}\text { Overall } \\
\text { Mean }\end{array}$ & VI \\
\hline 1. Administrator & 4.30 & $\mathrm{~A}$ & 3.54 & $\mathrm{O}$ & 3.89 & $\mathrm{O}$ & 4.35 & $\mathrm{~A}$ & 4.01 & $\mathrm{O}$ & 4.10 & $\mathrm{O}$ \\
\hline $\begin{array}{l}\text { 2. Non-teaching } \\
\text { personnel }\end{array}$ & 3.33 & So & 3.40 & $\mathrm{O}$ & 3.55 & $\mathrm{O}$ & 4.15 & $\mathrm{O}$ & 4.20 & A & 3.98 & $\mathrm{O}$ \\
\hline 3. SPED Teachers & 4.50 & A & 4.20 & $\mathrm{~A}$ & 4.35 & A & 4.41 & A & 4.58 & $\mathrm{~A}$ & 4.46 & A \\
\hline 4. Regular & 3.76 & $\mathrm{O}$ & 3.32 & So & 3.76 & $\mathrm{O}$ & 4.37 & A & 4.13 & $\mathrm{O}$ & 4.13 & $\mathrm{O}$ \\
\hline Teachers & & & & & & & & & & & & \\
\hline 5. Parents & 4.10 & $\mathrm{O}$ & 4.30 & A & 4.29 & A & 4.55 & A & 4.50 & A & 4.45 & A \\
\hline Grand Total & 4.00 & $\mathrm{O}$ & 3.75 & $\mathrm{O}$ & 4.00 & $\mathrm{O}$ & 4.36 & A & 4.28 & A & 4.22 & A \\
\hline
\end{tabular}

Legend. A - Always, O- Often, and So- Sometimes.

The findings explain that non-teaching personnel often performed as assessed by the five groups of 
Comia, B.

respondents in the inclusive education program. Therefore, from the initial phase to the transition phase, it is assumed that they are not functioning well in their responsibilities as part of the implementers of an inclusive education program. The result emphasizes that school administrators, non-teaching personnel, and regular teachers in the transition phase must give their full support, especially their presence in every phase. In addition, the parents and other stakeholders are evaluating them based on their roles. The finding explains that all of the implementers are equally important. Once you don't do your role as an implementer, it will affect the whole process. Therefore, the more effective you are, the more success the inclusive education will achieve.

The result justifies the statements of Cinco (2008) that non-teaching personnel rendered to an individual and its needs, such as inventory of each pupil, information regarding opportunities, counseling for all the students, follow-up studies, placement, and assisting teachers in case studies. Services for staff members in providing for leadership, securing the cooperation of the staff members, assisting teachers in utilizing information, organizing, and conducting in-service training. And also, services about the evaluation of follow-up service, making results available, surveys, securing the cooperation of parents and community, and conducting research to further improve guidance services.

\section{Table 3}

Role performance of the implementers as assessed by the five groups respondents in the inclusion phase

\begin{tabular}{lllllllll}
\hline \multirow{2}{*}{ Five - Group Respondents } & \multicolumn{2}{c}{ Administrator } & \multicolumn{2}{c}{ Non- teaching personnel } & \multicolumn{2}{c}{ SPED Teachers } & \multicolumn{3}{c}{ Overall } \\
& Overall Mean & VI & Overall Mean & VI & Overall Mean & VI & Overall Mean & VI \\
\hline 1. Administrator & 3.84 & $\mathrm{O}$ & 4.36 & $\mathrm{~A}$ & 4.01 & $\mathrm{O}$ & 4.40 & \\
2. Non-teaching personnel & 3.32 & $\mathrm{So}$ & 4.24 & $\mathrm{~A}$ & 3.63 & $\mathrm{O}$ & 3.73 & $\mathrm{O}$ \\
3. SPED Teachers & 3.78 & $\mathrm{O}$ & 4.32 & $\mathrm{~A}$ & 3.84 & $\mathrm{O}$ & 3.98 & $\mathrm{O}$ \\
4. Regular Teachers & 4.39 & $\mathrm{~A}$ & 4.64 & $\mathrm{~A}$ & 4.43 & $\mathrm{~A}$ & 4.49 & $\mathrm{~A}$ \\
5. Parents & 4.27 & $\mathrm{~A}$ & 4.49 & $\mathrm{~A}$ & 4.37 & $\mathrm{~A}$ & 4.38 & $\mathrm{~A}$ \\
Grand Total & 4.16 & $\mathrm{O}$ & 4.49 & $\mathrm{~A}$ & 4.24 & $\mathrm{~A}$ & 4.30 & $\mathrm{~A}$ \\
\hline
\end{tabular}

Legend. A - Always, O- Often, and So- Sometimes.

The result emphasizes that every eye is on the administrators because of their wide range of responsibilities. So, they must take care of themselves, most especially in supervising the inclusive education program as a whole. All of the other implementers are under his/her supervision. A high level of leadership is needed here to have a harmonious environment among all the implementers. The findings explain that the SPED teachers and regular teachers use everything they got to give the best for their students. These two work together to achieve their objectives in a particular child. This implies that the inclusion phase is not solely the responsibility of the regular teachers. The school administrator, regular teachers, and the SPED teachers must have a definite goal to achieve a specific task for the child who has special needs in an inclusive education program in the Division of Antipolo City. This confirms the statement of Barrameda (2007) that the success of the school operation is in the hands of the administrator. Without the administration of the administrator, the teachers and other subordinates cannot execute well without his supervision and the support of all the staff in the institution.

\section{Table 4}

Level of performance of the learners before and after the inclusion concerning academic performance

\begin{tabular}{lccccc}
\hline Competencies & & \multicolumn{3}{c}{ BEFORE } & \multicolumn{3}{c}{ AFTER } \\
\hline \multirow{3}{*}{ 1 Gross Motor Skills } & B & 1 & 7.1 & & \\
& I & 8 & 57.1 & 4 & 28.6 \\
& C & 5 & 35.7 & 10 & 71.4 \\
2 Socio-Emotional & Total & 14 & 100 & 14 & 100 \\
& B & 5 & 35.7 & & \\
& I & 9 & 64.3 & 9 & 64.3 \\
& C & & & 5 & 35.7 \\
\hline
\end{tabular}


Inclusive education program in the division of Antipolo City: Basis for implementation model

Table 4 ...continued

\begin{tabular}{|c|c|c|c|c|c|}
\hline \multirow{2}{*}{ Competencies } & & \multicolumn{2}{|c|}{ BEFORE } & \multicolumn{2}{|c|}{ AFTER } \\
\hline & & $\mathrm{f}$ & $\%$ & $\mathrm{f}$ & $\%$ \\
\hline \multirow{4}{*}{3 Listening and Watching } & B & 11 & 78.6 & 4 & 28.6 \\
\hline & I & 3 & 21.4 & 8 & 57.1 \\
\hline & $\mathrm{C}$ & & & 2 & 14.3 \\
\hline & Total & 14 & 100 & 14 & 100 \\
\hline \multirow{4}{*}{4 Speaking } & B & 9 & 64.3 & 1 & 7.1 \\
\hline & I & 5 & 35.7 & 8 & 57.1 \\
\hline & $\mathrm{C}$ & & & 5 & 35.7 \\
\hline & Total & 14 & 100 & 14 & 100 \\
\hline \multirow{4}{*}{5 Reading } & B & 9 & 64.3 & 2 & 14.3 \\
\hline & I & 4 & 28.6 & 7 & 50 \\
\hline & $\mathrm{C}$ & 1 & 7.1 & 5 & 35.7 \\
\hline & Total & 14 & 100 & 14 & 100 \\
\hline \multirow{4}{*}{6 Writing } & B & 4 & 28.6 & 1 & 7.1 \\
\hline & I & 8 & 57.1 & 4 & 28.6 \\
\hline & $\mathrm{C}$ & 2 & 14.3 & 9 & 64.3 \\
\hline & Total & 14 & 100 & 14 & 100 \\
\hline \multirow{4}{*}{7 Mathematics } & $\mathrm{B}$ & 6 & 42.9 & 1 & 7.1 \\
\hline & I & 7 & 50 & 5 & 35.7 \\
\hline & $\mathrm{C}$ & 1 & 7.1 & 8 & 57.1 \\
\hline & Total & 14 & 100 & 14 & 100 \\
\hline \multirow{4}{*}{8 Language } & B & 11 & 78.6 & 4 & 28.6 \\
\hline & I & 3 & 21.4 & 9 & 64.3 \\
\hline & $\mathrm{C}$ & & & 1 & 7.1 \\
\hline & Total & 14 & 100 & 14 & 100 \\
\hline \multirow{4}{*}{9 Life- Science } & B & 11 & 78.6 & 1 & 7.1 \\
\hline & I & 3 & 21.4 & 12 & 85.7 \\
\hline & $\mathrm{C}$ & & & 1 & 7.1 \\
\hline & Total & 14 & 100 & 14 & 100 \\
\hline
\end{tabular}

Legend. B- Beginning, I - Improving, and C- Consistent.

The finding reveals that there is evident progress of learners because of the changes in academic performance before and after the inclusion program. This implies that the success of the inclusion program is a collaborative effort of regular teachers because it is a continuous process in which these two professionals are always involved. The result explains that wherever you are in the educational system, there is always learning. However, learning is more evident when collaboration and cooperation within the regular teachers, Sped teachers, and the parents. This affirms the statement of Pangan (2009) that an increase in the students' academic performance is greatly achieved when the materials used are selected and implemented concerning relevance, meaningfulness, and specific goals that are most applicable to the needs of the students.

Table 5

Level of performance of the learners before and after the inclusion concerning behavior.

\begin{tabular}{|c|c|c|c|c|c|c|c|c|c|c|c|c|c|c|c|}
\hline \multirow{3}{*}{ Behavior } & \multicolumn{8}{|c|}{ BEFORE } & \multicolumn{7}{|c|}{ AFTER } \\
\hline & \multicolumn{2}{|c|}{$\mathrm{HC}$} & \multicolumn{2}{|c|}{$\mathrm{CC}$} & \multicolumn{2}{|c|}{$\mathrm{SC}$} & \multicolumn{2}{|c|}{$\mathrm{NC}$} & \multicolumn{2}{|c|}{$\mathrm{HC}$} & \multicolumn{2}{|c|}{$\mathrm{CC}$} & \multicolumn{2}{|c|}{$\mathrm{SC}$} & $\mathrm{NC}$ \\
\hline & f & $\%$ & $\mathrm{f}$ & $\%$ & $\mathrm{f}$ & $\%$ & $\mathrm{f}$ & $\%$ & $\mathrm{f}$ & $\%$ & $\mathrm{f}$ & $\%$ & $\mathrm{f}$ & $\%$ & f $\%$ \\
\hline $\begin{array}{l}\text { 1. Cooperates in group } \\
\text { activities }\end{array}$ & & & & & 14 & 100 & & & & & 2 & 14.3 & 12 & 85.7 & \\
\hline $\begin{array}{l}\text { 2. reacts Realistically to } \\
\text { criticism }\end{array}$ & & & & & 9 & 64.3 & 5 & 35.7 & & & & & 14 & 100 & \\
\hline $\begin{array}{l}\text { 3. Exhibits acceptable } \\
\text { responses to a given } \\
\text { situation }\end{array}$ & & & & & 14 & 100 & & & & & 12 & 85.7 & 2 & 14.3 & \\
\hline $\begin{array}{l}\text { 4. Refrains from doing } \\
\text { negative behaviors. }\end{array}$ & & & & & 10 & 71.4 & 4 & 28.6 & & & 4 & 28.6 & 10 & 71.4 & \\
\hline $\begin{array}{l}\text { 5. Adjusts positively to } \\
\text { the varied situation. }\end{array}$ & & & 4 & 28.6 & 10 & 71.4 & & & & & 4 & 28.6 & 10 & 71.4 & \\
\hline $\begin{array}{l}\text { 6. Responds readily to } \\
\text { management efforts. }\end{array}$ & & & & & 11 & 78.6 & 3 & 21.4 & & & 7 & 50 & 7 & 50 & \\
\hline
\end{tabular}


Comia, B.

Table 5 ...continued

\begin{tabular}{|c|c|c|c|c|c|c|c|c|c|c|c|c|c|c|c|}
\hline \multirow{3}{*}{ Behavior } & \multicolumn{8}{|c|}{ BEFORE } & \multicolumn{7}{|c|}{ AFTER } \\
\hline & \multicolumn{2}{|c|}{$\mathrm{HC}$} & \multicolumn{2}{|c|}{$\mathrm{CC}$} & \multicolumn{2}{|c|}{$\mathrm{SC}$} & \multicolumn{2}{|c|}{$\mathrm{NC}$} & \multicolumn{2}{|c|}{$\mathrm{HC}$} & \multicolumn{2}{|c|}{$\mathrm{CC}$} & \multicolumn{2}{|c|}{$\mathrm{SC}$} & $\mathrm{NC}$ \\
\hline & $\mathrm{f}$ & $\%$ & $\mathrm{f}$ & $\%$ & f & $\%$ & $\mathrm{f}$ & $\%$ & $\mathrm{f}$ & $\%$ & $\mathrm{f}$ & $\%$ & $\mathrm{f}$ & $\%$ & $\mathrm{f}$ \\
\hline $\begin{array}{l}\text { 7. Exhibits only a single } \\
\text { behavior problem. }\end{array}$ & & & 3 & 21.4 & 6 & 42.9 & 5 & 35.7 & & & 5 & 35.7 & 9 & 64.3 & \\
\hline $\begin{array}{l}\text { 8. Exhibits behavior } \\
\text { problem/s that is/are easy } \\
\text { to explain. }\end{array}$ & & & 3 & 21.4 & 11 & 78.6 & & & & & 5 & 35.7 & 9 & 64.3 & \\
\hline $\begin{array}{l}\text { 9. Performs academically } \\
\text { within-grade expected } \\
\text { level. }\end{array}$ & & & 5 & 35.7 & 9 & 64.3 & & & & & 6 & 42.9 & 8 & 57.1 & \\
\hline $\begin{array}{l}\text { 10. Is accepted/ liked by } \\
\text { peers. }\end{array}$ & & & 1 & 7.1 & 13 & 92.9 & & & & & 7 & 50 & 7 & 50 & \\
\hline $\begin{array}{l}\text { 11. Behaves realistically } \\
\text { without excessive } \\
\text { fantasizing daydreaming. }\end{array}$ & & & 1 & 7.1 & 13 & 92.9 & & & 1 & 7.1 & 4 & 28.6 & 9 & 64.3 & \\
\hline $\begin{array}{l}\text { 12. Exhibits } \\
\text { age-appropriate maturity } \\
\text { level. }\end{array}$ & & & & & 9 & 64.3 & 5 & 35.7 & & & 7 & 50 & 7 & 50 & \\
\hline $\begin{array}{l}\text { 13. Responds positively to } \\
\text { learning experiences. }\end{array}$ & & & 1 & 7.1 & 13 & 92.9 & & & & & 3 & 21.4 & 11 & 78.6 & \\
\hline $\begin{array}{l}\text { 14. Gets over upsetting } \\
\text { incidents quickly. }\end{array}$ & & & 2 & 14.3 & 12 & 85.7 & & & & & 2 & 14.3 & 12 & 85.7 & \\
\hline $\begin{array}{l}\text { 15. Shows sincere concern } \\
\text { about self-improvement. }\end{array}$ & & & 4 & 28.6 & 10 & 71.4 & & & & & 7 & 50 & 7 & 50 & \\
\hline
\end{tabular}

Legends. HC - Highly Characteristics, SC - Slightly Characteristics, CC - Characteristics of a Child, and NC - Not Characteristic.

The findings explain that behavior must be observed first rather than academic performance because you cannot give and teach knowledge when they are not ready to receive it through their specific behavioral problems. The results describe that learners must be exposed to academic activities and the activities that will improve their behavior in every situation, most especially when it talks about cooperation in group activities in a regular class. The finding implies that the role of the parent in the behavioral aspect of the learner serves a big contribution, most especially in taming their children. In addition, there is more exposure at home rather than in school because the hours that they are staying at school is only limited.

The result of the present study is consistent with the findings of Moges and Weber (2014) that parents have a big outcome on their child's emotional development. Being physically present may not be enough for a child, and all that matters is their parent's emotional attachment to them. If the parent is not emotionally connected to their child, they will struggle to regulate their emotions and interact appropriately with others.

\section{Table 6}

Performance of the learners before and after inclusion concerning academic performance and behavior

\begin{tabular}{lllll}
\hline & $\mathrm{X}^{2} \mathrm{c}$ & Sig. & Ho & VI \\
\hline Academic & 7.54 & 0.023 & $\mathrm{R}$ & $\mathrm{S}$ \\
Behavior & 9.33 & 0.002 & $\mathrm{R}$ & $\mathrm{S}$ \\
\hline
\end{tabular}

The findings reveal that the learners' achievement in performance and progress in behavior can be attained through the inclusion program. Although there are different classroom set-u, teachers, and classmates, the learners can grow in these two aspects. The collaboration of the implementers, especially the SPED and regular teachers, is relatively good. This implies that inclusive education is effective based on the rapid growth of the learners in academic and behavioral aspects. It is very clear for the teachers that they should provide special programs and related services to meet their needs. The efforts of the implementers are geared towards the intensification of measures to ensure quality education.

This confirms the statement of Entwistle (2009) that various factors in the learning environment and the student themselves affect the way they go about learning and studying describes a model in which he discerned three groups of influencing factors on student learning: student characteristics, teaching characteristics, and prior 
knowledge, intellectual abilities, learning style, and personality, attitudes to courses, motivation, work habits, and study skills. Teaching characteristics encompass level, pace, structure, clarity, explanation, enthusiasm, and empathy to departmental characteristics belong course design and objectives, earning materials, assessment procedure, workload, freedom of choice, and study skills support.

\section{Conclusions}

On the performance of the implementers in the Inclusive Education Program as assessed by five- groups of respondents in the different phases. It was found out that the school administrators, special education teachers, regular teachers, and parents always perform their roles in the different phases of the Inclusive education program. In contrast, the non-teaching personnel often perform their roles in implementing the Inclusive Education Program in the Division of Antipolo City. It was also found out that the level of performance of the learners improved after attending the inclusion program, and they are still manageable. Therefore, they can expect achievement and progress in both academic performance and behavior. Based on the study's findings, the Inclusive Education Program effectively enhances the academic performance and behavioral progress of the learners, and Child Find is the prerequisite to a successful Inclusive Education Program. Furthermore, since the placement of learners in the program is determined the effective child-find strategies.

Acknowledgment - The researcher wants to extend his sincerest gratitude to the following persons who rendered their valuable support, assistance, kindness, and encouragement in the completion of this study, Dr. ROMMEL C. BAUTISTA, Schools' Division Superintendent of Antipolo City, for allowing the researcher to conduct his study; Dr. MARITA R. CANAPI, University President, for stirring the researchers initiative to write a research in this university; Dr. ALLEN U. BAUTISTA, Dean, Graduate School, URS, for his compassionate supervision and meaningful suggestions for the development of the study; Dr. ROSA F. PORTILLO, Thesis Adviser, for her knowledge, expertise and grateful heart toward the fulfillment of this study; Dr. MARIAM M. ESTRABO, Chairman, Panel of Oral Examiner, for her ardent dedication, effort and patience, for the necessary suggestions and ' encouragements to pursue the study; Dr. AURORA F. TRINIDAD, Research Panel Member, for the trust and unending support to make this study more substantial; Dr. JOSE E. BINALUYO, Research Statistician, for his technical assistance in providing the researcher the knowledge and expertise for the appropriate Statistical , treatment in the study; Dr. GLENN M. ISON, Research Panel Member, for his constructive suggestions, comments, and guidance to make this research possibIe; Dr. LENI A. AVECILLA, Research Consultant, for her availability and supervision of the study; Dr. FLORA D. CAHAPAY, School Principal, Bagong Nayon I Elementary School for her selfless grant of helping hand in the progress of the study; Mr. ERWIN C. ACORDA, School Principal, Bagong Nayon IV Elementary School, for his great accommodation of this study. Furthermore, to his parents, Mr. RUBEN T. COMIA AND Mrs. GLORIA M. COMIA for their moral support; and Finally, to GOD ALMIGHTY for showering the researcher with wisdom, knowledge, and strength for the completion of this study.

\section{References}

Adunola, L. (2011). Teaching methods and strategies of regular teachers in special education (Unpublished

Master's Thesis). Roosevelt University.

Agno, L., et al. (2008). Curriculum and instruction. Teacher Education Council.

Agus, A. (2011). Enhancing production performance and customer performance through total quality management strategies for competitive advantage (Unpublished Master's thesis). Roosevelt college of education. https://doi.org/10.1016/j.sbspro.2011.09.019

Aikin, W. M. (2009). The story of the eight-year study: With conclusions and recommendations. Harper.

Barette, M. (2008). Practices of teachers in teacher-centered approach. NJ.

Busto, A. V. (1997). Constitution of the Republic of the Philippines. 
Comia, B.

Cagney, G. (2009). Accommodation and modification in special education. Xavier University.

Cassady, J. (2011). Teacher's attitudes toward the inclusion of students with autism and emotional behavioral disorder. Electronic Journal for Inclusive Education, Xavier University.

Chalmers, F. (2008). Empirical studies in teaching experiences. CA.

Cooke, S. (2008). Behavior management reports. Retrieved from http://behaviourmanagementreprot.weebly.com/key-theorist.html

Cummings, L. (2014). The parents' role and understanding towards the upbringing the children. Divecha.

Department of Education Official Website. (2008). DO 117, s. 1997 - Institutionalizing the SpEd program at all levels. Inclusive education as strategy for increasing participation rate of children. Retrieved from http://deped.gov.ph/orders/do-117-s-1997

Department of Education Official Website. (2009). DO 72, s. 2009 - Inclusive education as strategy for increasing participation rate of children. Retrieved from http://deped.gov.ph/orders/do-72s-2009

Department of Education Official Website. (2017). DepEd ensures inclusive education for learners with special needs. Retrieved from http://www.deped.gov.ph/pressrelease/deped-ensures-inclusive-education-learners-special-needs

Entwistle, R. (2009). Factor's affecting the children's academic excellence. Curriculum modification. Xavier University.

Erickson, K, (2011). The principle of normalization: History and experience in Scandinavian countries: Theme disability and support. Uppsala University, Sweden.

European Agency for Development in Special Needs Education. (2010). Teacher education for inclusion. Retrieved from https://www.european-agency.org/sites/default/files/TE4l-Literature-Review.pdf

Facer, C. (2011). The participation of students in the twenty-first century. Xavier University.

Hall, B. (2010). Inclusion in pre-school. Concordia University Portland.

Hallahan, D., et al. (2010). Exceptional children: Introduction to special education (6 ${ }^{\text {th }}$ ed.). CA.

Hamilton, L. (2016). Teacher experience and student achievement. RAND Education.

Herz, L. (2007). Extent of institutional leaders and teaching staff. Xavier University.

Hussein et al. (2009). Best strategies and addressing difficult behavior of children with special needs.

Marquardt C. (2009). Roles of the administration and staff. The University of Wisconsin-Stout.

Mingoa, R. (2016). The online journal of quality in higher, impact of teachers' qualifications and experience on the performance of students (Vol. 3).

Moges \& Weber (2014). The online journal of emotional attachment of parents to the children with special needs (Vol 4), Issue 6.

Punzalan, T. (2007). Curriculum and instruction: Ang pagtuturong edukasyon sa pagpapahalaga at edukasyong pagkatao. Teacher Education Council.

Regan, et al. (2009). Optimizing teaching and learning: Practicing pedagogical research. Wiley-Blackwell.

Ricci, C. (2010). Effect of regular teachers in special education. CA.

Tamayao, A. (2013). Social dimensions of education. Rex Printing Company.

UNESCO. (2005). Guidelines for inclusion, ensuring access to education for all. Retrieved from http://unesdoc.org/images/0014/001402/140224e.pdf.

Wehmeyer, C. (2010). Impact of curriculum modifications on access to the general education curriculum for students with disabilities (Unpublished Master's thesis). Massachusetts University.

Winter, R., et al. (2009). Administering special education programs: A practical guide for school leaders. CA. Yao, J. (2015). Inclusive and segregated special education programs: Cost analysis, student achievement, and parent satisfaction (Unpublished Master's thesis). College of Education, UP Diliman, Quezon, City. 